EDUKACJA MIĘDZYKULTUROWA

2012, nr 1

ISSN 2299-4106

Dorota MisiejuK,

MirosŁaw SOBECKI

\title{
Krótka historia Katedry Edukacji Międzykulturowej Uniwersytetu w Białymstoku
}

Streszczenie: Opracowanie prezentuje działalność naukowo-badawczą Katedry Edukacji Międzykulturowej działającej pod kierunkiem prof. zw. dra hab. Jerzego Nikitorowicza na Wydziale Pedagogiki i Psychologii Uniwersytetu w Białymstoku. Jest to jeden z wiodących w Polsce ośrodków akademickich zajmujący się edukacją międzykulturową.

Słowa kluczowe: edukacja międzykulturowa, badania międzykulturowe, tożsamość, Katedra Edukacji Międzykulturowej.

Historia Katedry Edukacji Międzykulturowej działającej obecnie na Wydziale Pedagogiki i Psychologii Uniwersytetu w Białymstoku rozpoczęła się od powołania jesienią 1995 roku zakładu o takiej samej nazwie. Wówczas jeszcze nie istniał samodzielny uniwersytet w Białymstoku i dlatego prawnie zatwierdzono funkcjonowanie Zakładu głosowaniem Senatu Uniwersytetu Warszawskiego 18 października 1995 roku. Niemniej inicjatywa utworzenia struktury organizacyjnej wypływała z potrzeb i zainteresowań badawczych naukowców i adeptów nauki związanych ze środowiskiem akademickim Białegostoku. Inicjatorem, przywódcą i pierwszym organizatorem był wówczas prof. dr hab. Jerzy Nikitorowicz. To on zaczął kompletować zespół pracowników Wydziału, którzy jako podstawowe swoje zadanie badawcze widzieli w analizowaniu pogranicza i procesów społecznych związanych z wielokulturowością regionu oraz diagnozowaniu związanych z tym potrzeb w zakresie edukacji i wychowania. Powstanie Zakładu było wyrazem zainteresowania problematyką, ważną ze względu na aktualność tejże, ale także ze względu na położenie białostockiej uczelni. Kwestie wielo- i międzykulturowości, kontaktów między reprezentantami różnych kultur, kulturowych uwarunkowań funkcjonowania ucznia i szkoły, dziedzictwa kulturowego, czy wreszcie społeczno-kulturowej tożsamości w dynamicznie zmieniającym się świecie, kształtowały nowy, wyraźnie 
wyodrębniający się obszar badań oraz stawiały nowe wyzwania wobec szkoły i wychowania tak $\mathrm{w}$ wymiarze globalnym, jak i regionalnym. Ważną przestrzeń analiz nowej dynamicznie rozwijającej się dyscypliny - edukacji międzykulturowej - stanowiły pedagogiczne konteksty funkcjonowania mniejszości narodowych, które w ostatniej dekadzie XX wieku odzyskały pełnię autonomii, a ich działalność uzyskała niespotykaną dotychczas dynamikę.

W 1995 roku, tuż przed formalnym powołaniem Zakładu - ukazała się książka Nikitorowicza Pogranicze - Tożsamość - Edukacja międzykulturowa. Stanowiła ona swoisty manifest rodzącej się grupy, którą - obok samego profesora - tworzyli na początku Dorota Misiejuk, Jolanta Muszyńska, Danuta Byrwa i Mirosław Sobecki. Motywem przewodnim eksploracji prowadzonych siłami zespołu od samego początku stała się tożsamość, rozpatrywana w kontekście szeroko ujmowanej kategorii pogranicza. Pedagogika pogranicza uprawiana przez Zespół przede wszystkim ukazywała twórczy potencjał kulturowo zróżnicowanego świata. Założono, że kultura - będąc czynnikiem różnicującym - staje się jednocześnie podstawą do jednoczącego porozumienia. Przyjęto, że przy wykorzystaniu oddziaływań edukacyjnych właśnie kultura może i powinna przyczyniać się do rozwiązania bądź przynajmniej łagodzenia wielu problemów współczesnego świata manifestujących się w przejawach lokalnej codzienności.

Rok wcześniej - latem 1994 roku - wszyscy członkowie zespołu uczestniczyli w zorganizowanej w Ciechanowcu konferencji naukowej „Edukacja międzykulturowa w kręgu potrzeb, oczekiwań i stereotypów”. Podczas konferencji prezentowano główne kwestie, które miały być poddane eksploracji w następnych latach. Po raz pierwszy tak zdecydowanie zwrócono uwagę na związek refleksji teoretycznej z praktyką. Stąd też liczna obecność osób bezpośrednio zaangażowanych w pracę środowiskową na rzecz pluralizmu kulturowego. Już wówczas zauważono potrzebę metodycznego przygotowania studentów, przyszłych nauczycieli, animatorów kultury i pracy środowiskowej, do działań promujących i afirmujących różnorodność kulturową. Na konferencji miało także miejsce bardzo ważne, spektakularne wydarzenie. Otóż z inicjatywy prof. zw. dra hab. Tadeusza Lewowickiego powołana została Federacja Zespołów Badań Pogranicza, będąca pierwszą próbą - jak później miało się okazać, próbą udaną - jednoczenia wysiłków reprezentantów różnych ośrodków w kraju skupionych wokół idei edukacji międzykulturowej. To w tej sytuacji ostatecznie wykreowała się grupa osób zainteresowanych problematyką edukacji międzykulturowej, pracujących dotąd w innych jednostkach organizacyjnych Wydziału 
Pedagogiki i Psychologii, które skupił wokół siebie prof. Jerzy Nikitorowicz. Poczynania rodzącego się zespołu włączone zostały od razu w rytm pracy innych ośrodków, które promowały idee edukacji międzykulturowej. Po konferencji wydano publikację, która w zamierzeniu miała otwierać cykl poświęcony nowej w środowisku białostockich pedagogów problematyce. Książka przygotowana pod redakcją Nikitorowicza nosiła tytuł Edukacja międzykulturowa: w kręgu potrzeb, oczekiwań $i$ stereotypów. Co ważne, znalazły się w niej także głosy osób reprezentujących kraje ościenne: Niemcy, Litwę i Białoruś. Międzynarodowy wymiar organizowanych spotkań naukowych miał się odtąd stać tradycją. Już wkrótce na konferencjach zjawili się także goście z Czech, Ukrainy, Stanów Zjednoczonych, Wielkiej Brytanii i Australii.

W 1997 roku ukazała się kolejna książka przygotowana przez Nikitorowicza. Nosiła ona tytuł Rodzina wobec wyzwań edukacji międzykulturowej. W publikacji położono nacisk na najwcześniejszy okres kształtowania się tożsamości młodego człowieka, a także na kulturowe aspekty funkcjonowania rodziny mające znaczenie dla poczucia zakorzenienia. W tym samym roku wydana została praca Sobeckiego Funkcja etniczno-kulturowa szkół mniejszości narodowych. Była ona efektem zainteresowania autora problematyką funkcjonowania szkół mniejszości białoruskiej i litewskiej i stanowiła pokłosie badań przeprowadzonych w północno-wschodniej Polsce kilka lat wcześniej. Rok później (1998) Dorota Misiejuk we współpracy z Elżbietą Czykwin wydaje książkę Dwujęzyczność a dwukulturowość w perspektywie psychopedagogicznej. Była ona rezultatem pobytu autorki w Kanadzie i analizowania przez nią problematyki nauczania języka etnicznego jako języka obcego w środowisku kanadyjskich Ukraińców.

Niebagatelne znaczenie dla realizacji idei edukacji międzykulturowej ma nie tylko rodzina, ale także cały szereg innych instytucji, które tworzą tkankę życia społecznego. Wśród nich szczególną rolę odgrywa oczywiście szkoła. Na spotkaniu naukowym zorganizowanym w 1998 roku w Białymstoku zwrócono uwagę na socjalne i religijne aspekty funkcjonowania grup odmiennych kulturowo. Niekiedy - na przykład w sytuacji Romów - konteksty socjalne nierozerwalnie związane ze stricte kulturowymi współtworzą istotę odrębności grup mniejszościowych i sposób ich spostrzegania, a następnie wyodrębniania przez większość. Rozważano też wyzwania stojące przed różnorakimi instytucjami w związku z integracją Polski ze strukturami europejskimi. Efektem spotkania była publikacja zatytułowana Edukacja międzykulturowa w wymiarze instytucjonalnym, wydana w roku 1999. 
Od początku myślenia o edukacji międzykulturowej bardzo ważną kwestią było przełożenie rozważań naukowych na grunt pedagogicznej praktyki. Wkrótce przygotowano wstępną koncepcję realizacji zajęć kursowych z edukacji międzykulturowej dla studentów pedagogiki. Opierała się ona na powiązaniu problematyki tożsamości i zakorzenienia z postawami wobec odmienności kulturowej. W środowisku, gdzie współistnienie odmiennych kultur jest wielusetletnią tradycją takie rozwiązanie nasuwało się nieomal samo. W oddziaływaniach dydaktycznych postanowiono więc nawiązać wprost do dziedzictwa kulturowego narodów i religii stanowiących niegdyś piękną mozaikę wielokulturowej Rzeczypospolitej w jej wschodniej części. Mimo że XX wiek tak znacząco odmienił mapę polityczną, a w konsekwencji także rozmieszczenie ludności, północno-wschodnia Polska nadal pozostała swoistym laboratorium wielokulturowości, na którym można było oprzeć realizację idei edukacji międzykulturowej. Prezentując w dydaktyce swoistości poszczególnych grup, próbowano wskazywać na to, co jest między nimi, na to, co pozwala budować mosty porozumienia. W konstruowaniu programu przedmiotu wiele uwagi poświęcono kwestii komunikacji międzykulturowej. Zapoznanie z elementami dziedzictwa odmiennych grup, z którymi wchodzimy w interakcję stanowiło tu podstawę do zrozumienia odmienności i kształtowania pożądanych postaw, tolerancji, dialogu, symbiozy kulturowej.

Hasło kolejnej konferencji zorganizowanej w roku 2000 brzmiało: „Kultury tradycyjne a kultura globalna. Konteksty edukacji międzykulturowej”. Podjęto na niej dylematy związane z funkcjonowaniem kultur tradycyjnych w konfrontacji z kulturą globalną. Szczególnie interesowała nas problematyka ochrony dziedzictwa kulturowego, wartości rdzennych i pierwszych warstw tożsamości niezbędnych w dobie globalizacji do skutecznej komunikacji międzykulturowej i budowania wielowymiarowej tożsamości kulturowej. Główną intencją było podkreślenie ważnych zadań edukacji międzykulturowej związanych z otwieraniem się kultur, rezygnacją z kulturowych gett, integracją społeczności wokół wartości podstawowych. Chodziło także o zwrócenie uwagi na nowe zadania społeczeństwa, grup większościowych, wobec mniejszości kulturowych, wymagających szczególnej troski i działań niwelujących lęk w ich komunikacji z kulturową większością. Staraliśmy się uwypuklić, że każde dążenie do jedności jest zjawiskiem pozytywnym, o ile prowadzi do wzrostu nieantagonistycznej świadomości odrębności oraz dbałości o wspólnie uznawane wartości. Jednocześnie jednak za godną podkreślenia uznaliśmy konieczność otwierania się na inne kultury, sprzyjającą w efekcie 
głębszemu poznawaniu siebie i tworzeniu atmosfery wspomagającej procesy integracji. To właśnie integrację eksponowano jako czynnik decydujący o zachowaniu ciągłości i tożsamości kulturowej całych społeczeństw. Przy tym rozumiano ją przede wszystkim jako zmierzanie do jedności w różnorodności. Integracja może dotyczyć tylko tego, co łączy, w celu sprawniejszego, wspólnego pokonywania trudności, a w żadnym wypadku nie może oznaczać unifikacji, czy wręcz eliminacji odmienności. Podkreślano, że dobrze rozumiana integracja jest mediatorem między tym, co lokalne i tradycyjne a tym, co globalne i na wskroś nowoczesne, między tym, co historyczne a tym, co współczesne, wreszcie między tym, co obce a tym, co własne.

Także w roku 2000 ukazała się kolejna książka Nikitorowicza Młodzież pogranicza kulturowego Białorusi, Polski i Ukrainy wobec integracji europejskiej. Była ona efektem udziału Profesora w szeroko zakrojonym projekcie badawczym „Poczucie tożsamości narodowej i plany życiowe młodzieży pograniczy". Przedmiotem swych rozważań autor uczynił procesy związane z kształtowaniem tożsamości kulturowej młodzieży zamieszkującej pogranicza oraz jej opinie na tematy dotyczące procesu integracji europejskiej. Badania dotyczyły także uznawanych przez młodzież wartości, jej celów życiowych oraz postaw wobec reprezentantów innych grup etnicznych. Obraz eksploracji dopełniony został przez rozważania dotyczące świadomości badanych w zakresie problemów kraju respondentów, jak i kraju sąsiadów. Z kolei rok 2001 zaznaczył się wydaniem dwutomowej publikacji Kultury tradycyjne a kultura globalna. Konteksty edukacji międzykulturowej pod redakcją Nikitorowicza, Misiejuk i Sobeckiego. Książka miała na celu uchwycenie ambiwalencji dynamizmów charakteryzujących procesy kulturowe i edukacyjne końca XX wieku. Tak jak w przypadku wszystkich poprzednich książek stanowiących efekt spotkań naukowych, znaczące miejsce zajęła w niej tożsamość i rola instytucji edukacyjnych w jej kształtowaniu. Przygotowując kolejne z cyklu spotkanie naukowe zatytułowane „Międzygeneracyjna transmisja dziedzictwa kulturowego", które odbyło się w 2002 roku w Augustowie, postanowiono skoncentrować się na problematyce transferu tradycji. Rozważano kwestie jej ciągłości i zmiany. Zastanawiano się nad miejscem rodziny, zwłaszcza rodziców i dziadków, w przekazie tradycji, nad jej znaczeniem w życiu współczesnego człowieka. Kontynuując problematykę poprzedniego spotkania, próbowano także zainicjować dyskusję na temat wzajemnych relacji między tym, co globalne a tym, co lokalne, ze szczególnym uwzględnieniem transmisji wartości w przestrzeni kultury regionalnej. Efektem spotkania były dwa tomy 
opublikowane w 2003 roku. Pierwszy z nich nosi tytuł Międzygeneracyjna transmisja dziedzictwa kulturowego. Społeczno-kulturowe wymiary przekazu, a drugi Międzygeneracyjna transmisja dziedzictwa kulturowego. Globalizm versus regionalizm. Obydwa tomy zostały przygotowane przez Jerzego Nikitorowicza, Jolantę Muszyńską i Jerzego Halickiego.

Kontynuacją podejmowanej problematyki był projekt badawczy, który przygotowano na konkurs ogłoszony przez Komitet Badań Naukowych. W ramach szeroko zakrojonego przedsięwzięcia „Kultura polska w nowej Europie" koordynowanego przez Instytut Badań Literackich PAN podjęto do realizacji rozpisany na trzy lata projekt badawczy „Kultura polska na pograniczach. Międzygeneracyjna transmisja dziedzictwa kulturowego mniejszości narodowych". Jego zasadniczym celem jest zdiagnozowanie stanu kompetencji kulturowych przedstawicieli mniejszości narodowych: polskiej - zamieszkałej w Republice Białoruś i białoruskiej - zamieszkałej w Polsce oraz roli relacji międzygeneracyjnych w budowaniu kompetencji kulturowych w obrębie kultury etnicznej, nie będącej kulturą większościową. Do badań wybrano członków mniejszości narodowych najbardziej aktywnych, o największych aspiracjach edukacyjnych, aktualnie studiujących bądź będących absolwentami Uniwersytetu w Białymstoku. Szczególne miejsce w badaniach przeznaczono kulturze symbolicznej związanej z kanonem kultury narodowej, zwłaszcza kultury wysokiej. Zainteresowanie badaczy skupiło się zarówno na interpretacji przez badanych wybranych, kanonicznych symboli kulturowych wraz z interakcyjnymi uwarunkowaniami tychże interpretacji, jak też na wyselekcjonowaniu osób dysponujących najlepszymi kompetencjami. W tym celu prowadzono pogłębione badania jakościowe obejmujące rodziny badanych (ich rodziców i dziadków). W efekcie badań przygotowano raport, w którym nakreślono obraz przekazu dziedzictwa kulturowego, uchwycony w okresie niezwykle dynamicznych przemian społecznych i kulturowych zachodzących w naszej części Europy.

Latem 2004 roku w Augustowie odbyło się kolejne spotkanie naukowe poświęcone problematyce edukacji międzykulturowej pod hasłem „Region. Tożsamość. Edukacja międzykulturowa”. Tym razem skoncentrowano się na różnych kontekstach budowania kulturowych więzi regionalnych bądź lokalnych. Szczególną uwagę zwrócono na język i historię jako znaczące przestrzenie konstruowania więzi. W związku z realizacją grantu KBN kolejną konferencję zaplanowaną $\mathrm{w}$ ramach przedsięwzięcia badawczego organizowano już po roku. A w 2006 roku znów spotkaliśmy się w cyklicznym 
dwuletnim rytmie. W Olecku obradowano pod hasłem „Etniczność i obywatelskość w nowej Europie - konteksty edukacji międzykulturowej”. Kolejną konferencją Katedry było spotkanie w 2010 roku poświęcone zarówno podsumowaniom, jak i wyznaczaniu nowych tropów badawczych. W trakcie prac konferencji analizowano dynamikę i efektywność organizacyjną badaczy skupionych wokół problematyki pedagogiki międzykulturowej, debatowano o wadze wielokulturowości i procesach społecznych, które odzwierciedlone w projektach badawczych służą pedagogom do kreowania nowych innowacyjnych podejść w wychowaniu i edukacji.

Niezwykle ważnym etapem w historii zespołu było opublikowanie przez kierującego nim profesora Nikitorowicza książki Kreowanie tożsamości dziecka. Wzywania edukacji międzykulturowej. Stanowiła ona swoiste podsumowanie poszukiwań autora dotyczących problematyki edukacji międzykulturowej, zwłaszcza w sferze tożsamości. Jak podkreśla sam autor, zawarta w książce wizja edukacji międzykulturowej jest efektem zarówno poszukiwań badawczych, jak i doświadczeń związanych z dziesięcioleciem istnienia na Wydziale Pedagogiki i Psychologii Zakładu Edukacji Międzykulturowej. W zwieńczeniu swojej pracy Nikitorowicz zaproponował nową holistyczną koncepcję edukacji międzykulturowej, opartą na wielowymiarowej i wielopłaszczyznowej tożsamości i kompetencjach komunikacyjnych, sprzyjających budowaniu postaw tolerancji wobec odmienności kulturowej.

Kamieniem milowym w historii zespołu skupionego wokół profesora było powołanie przez Senat Uniwersytetu w Białymstoku Katedry Edukacji Międzykulturowej. Wchodząc w kolejny okres działalności, dostrzegamy nowe wyzwania, które stwarzają pole do jego rozwoju. Przede wszystkim za efekt owego „nowego otwarcia” można by uznać wydanie książki Sobeckiego: Kultura symboliczna a tożsamość. Studium tożsamości kulturowej Polaków na Grodzieńszczyźnie z perspektywy edukacji międzykulturowej. W pracy tej autor analizuje zagadnienia polskiej tożsamości kulturowej na pograniczu, prezentując potrzebę, i co ważniejsze, metodę i narzędzie badawcze do analiz teorii wielowymiarowej tożsamości kulturowej jednostek. Poprzez tę pracę i oczywiście szeroki dorobek naukowy dr. Sobeckiego zespół zyskał kolejnego samodzielnego pracownika nauki.

Widząc potrzebę poszerzenia i intensyfikacji działań badawczych, pracownicy Katedry rozpoczęli swoistą ofensywę prezentowania badań własnych na forum europejskim. Jako aktywny członek międzynarodowej platformy uczelni akademickich Europy w ramach projektu „Children's Identity and 
Citizenship in Europe", pracownicy Katedry brali udział w wielu przedsięwzięciach badawczych, które z jednej strony stały się forum prezentowania osiągnięć i efektów pracy Zespołu, a z drugiej, poprzez współpracę, doświadczenia w zakresie edukacji wielokulturowej i międzykulturowej zyskiwały nowy europejski wymiar. W 2011 roku pracownicy Katedry wzięli udział w międzynarodowym przedsięwzięciu wydawniczym i w ramach serii wydawniczej Crossculture ukazały się teksty Sobeckiego i Misiejuk. Lata 2007-2012 to także czas poświęcony na międzynarodową współpracę w zakresie projektów edukacyjnych. W ramach programów „Grundtvig” i „Commenius” pracownicy Katedry podejmowali wyzwania konstruowania programów edukacyjnych dla młodzieży, osób starszych, a także zajmowali się kreowaniem programów integracyjnych dla imigrantów. Ich wiedza i kompetencje w zakresie procesów społecznych wielokulturowości i zasad w edukacji międzykulturowej niewątpliwie wzbogaciły owe programy. Aktywność na arenie międzynarodowej zintensyfikowała współpracę z zaprzyjaźnionymi ośrodkami w kraju. Nadzieje budzi powołany przed kilkoma laty przy Komitecie Nauk Pedagogicznych PAN Zespół Pedagogiki Kultury i Edukacji Międzykulturowej, którym kieruje profesor Jerzy Nikitorowicz. Konkretne, wymierne efekty wieloletnich kontaktów i współpracy w ramach Federacji Zespołów Badań Pogranicza kierowanym przez prof. Tadeusza Lewowickiego zobrazowane zostały wydaniem zbiorowej pracy o funkcjonowaniu języka polskiego w państwach europejskich: Szkolnictwo z polskim językiem nauczania w państwach europejskich - stan, problemy, perspektywy. Red. T. Lewowicki, J. Nikitorowicz, A. Szczurek-Boruta. Białystok - Cieszyn - Warszawa 2010. Wielowymiarowa i wielodyscyplinarna analiza funkcji i społecznej obecności języka polskiego w państwach europejskich, co jest treścią tej pracy, wskazuje na znaczenie języka dla procesów tożsamościowych i pokazuje jego znaczenie jako elementu kultury współcześnie. Z radością odnotowaliśmy też zainteresowanie problematyką edukacji międzykulturowej nie tylko w perspektywie regionalnej czy europejskiej, ale także ogólnokrajowej. Milowym krokiem w propagowaniu podejścia wielokulturowego okazała się praca Nikitorowicza wydana w Wydawnictwach Akademickich i Profesjonalnych, zatytułowana Edukacja regionalna i międzykulturowa. Dzieło to na rynku wydawniczym można postrzegać z jednej strony jako fundamentalną analizę wiedzy o człowieku i grupach społeczno-kulturowych z perspektywy pedagogiki międzykulturowej, ale także jako podręcznik akademicki, zapoznający studentów $\mathrm{z}$ analizami pedagogiki międzykulturowej. 
Pracownicy Katedry nawiązali także ścisłą współpracę badawczą z Zakładem Pedagogiki Społecznej w ramach macierzystego Wydziału i korzystając z potencjału twórczego obu zespołów, zgłosili do konkursu projekt badawczy pt. „Kompetencje do komunikacji międzykulturowej w warunkach tradycyjnej wielokulturowości i procesów migracyjnych", który wygrali. Obecnie jest on w fazie realizacji i prezentacja wyników badań planowana jest na jesień 2012 roku. Będzie to kolejna konferencja Katedry - otwierająca do badań, jak się wydaje, kolejną przestrzeń życia społecznego.

\section{A brief history of the Chair of Intercultural Education in University of Białystok}

\section{Summary}

The study presents the research activity of the Chair of Intercultural Education supervised by Professor Jerzy Nikitorowicz at the Faculty of Pedagogy and Psychology of the University of Białystok. This unit is one of the leading academic centres which explore intercultural education. 